\title{
CONDUCTIVITY AND PARTICLE SIZE MEASUREMENT IN SANDY LOAM SOIL USING ORGANIC AMENDMENT
}

\author{
P. Jeyaseeli ${ }^{1, \bigotimes}$, F. Jeyamangalam ${ }^{2}$, S. Selvaraj ${ }^{3}$ and S. C. Vella Durai ${ }^{4}$ \\ 1,2Department of Physics, Sarah Tucker College (Autonomous), Tirunelveli-627007, India, \\ ${ }^{3} \mathrm{PG}$ and Research Department of Physics, The M.D.T. Hindu College, Tirunelveli-627004, India \\ ${ }^{4}$ Department of Physics, JP College of Arts \& Science, Agarakattu, Tenkasi-627852, India \\ (Affiliated to Manonmaniam Sundaranar University, Tirunelveli-627012, India) \\ ${ }^{凶}$ Corresponding Author: jeyaseeli.rkr@gmail.com
}

\begin{abstract}
An analysis of field study was undertaken at Karisalpatti in Cheranmahadevi block, Tirunelveli district of Tamil $\mathrm{Nadu}$, South India in 2018 and the conductivity measurement was done for the sandy loam soil which is situated at $8.60^{\circ}$ latitudes and $77.58^{\circ}$ longitudes. The analysis was highly focused on the soil by blending vermin compost (VC) at $17.5 \mathrm{t} \mathrm{ha}^{-1}$ concentration and also farmyard manure (FYM), vermin compost (VC) and Goat Manure (GM) at 17.5 $\mathrm{t} \mathrm{ha}^{-1}$ concentration. Before and after harvest the conductivity properties such as Electrical Conductivity (EC), Thermal Conductivity $(\mathrm{K})$ and Hydraulic Conductivity (HC) were studied. The observed conductivities reveal the presence of soil moisture capacity. The moisture content in the soil can conduct an electric current. The morphological appearance such as the shape and size of the sandy loam soil was studied using SEM characterization. From the EDAX spectrum, the mineral composition of organic matter was confirmed. Particle size analysis of the sandy loam soil reveals the intensity distribution of soil particles. The particle size study of soil structure was essential to predict the water holding capacity of the soil. Method of combining manures with the composted organics could be taken up; so that the physical properties of the soil are enhanced. Organic agriculture enhances the physical potential of the soil, underground water resources and also protects them from natural and human-induced degradation. Monitoring the soil's physical properties influence precision farming in climatic change. The organic amendment added sandy loam soil increases the water permeability, total porosity and large pores in the soil which were responsible for gravitational water movement in the soil. Organic amendments improve the hydrologic effects on soil physical properties such as hydraulic conductivity and moisture content. Increasing residue returns and adding organic amendment improves the soil water holding capacity. It positively influenced the yield. Thus it is concluded that the application of organic amendment contributes high yield attributes to the corn crop.
\end{abstract}

Keywords: Amendment, Conductivity, Electrical, Hydraulic, Harvest, Thermal.

RASĀYAN J. Chem., Vol. 14, No.1, 2021

\section{INTRODUCTION}

Organic manures enhanced soil fertility and led to an increase in crop productivity as compared to the control without organic manure ${ }^{1}$. The Bible depicts Moses taking Israelites to the fertile soil which was necessary for his people as they entered Canaan in $1400 \mathrm{BC}^{2}$. Conductivities in soil particles reveal as low conductivity in sand particle, medium conductance in silt particles and maximum conductivity in clay content. The high value of electrical conductivity affects crop yield ${ }^{2-7}$. The organic material is used to reduce the electrical conductivity of the sandy loam soil. Electrical conductivity points out the presence of ions content of solution which is directly proportional to the current-carrying capacity of soil reveals the soluble salts in the soil ${ }^{8}$. An intrinsic property of thermal conductivity reveals the capability of heat regime in the sandy loam soil. An organic amendment in the sandy loam soil minimizes the thermal conductivity and contributes the yield to be high.

Hydraulic conductivity depends on the pore size of soil particles and field density. The structural composition and morphological characteristics of farmyard manure in each size fraction were analyzed by SEM and EDAX respectively ${ }^{9}$. SEM and EDAX analysis provide essential information on the surface morphology of vermin compost and control samples. SEM micrographs of the final vermin compost Rasayan J. Chem., 14(1), 74-(2021) 
product produce a large number of external variations, which represents bio-degradation and organic waste using earth worms ${ }^{10}$. Sandy loam soil has group of soil particles with different shapes and sizes. Sandy loam soil consists of silt and clay which is most preferable for gardening with better drainage. Increasing organic matter in sandy loam soil contributes to significant differences in physical properties ${ }^{11}$. Patterning the dimension division of soil particles to have the continuous particle size division curve helps know the necessary soil properties such as pore distribution, water holding capacity, and hydraulic conductivity and heat absorption properties. The particle size studies taking possession of a low number of particle mass fractions ${ }^{12}$. Mostly investigator has depended upon a single particle size pattern at one time to exhibit a broad arrange of soil structure ${ }^{13}$. Identification of soil color, mineral content and nature of the organic matter are obtained by using a Scanning electron microscope ${ }^{14}$. SEM with EDAX is helpful to characterize the soil external appearance, structural division and chemical constituents of soils having ultrafine particles ${ }^{15}$. SEM with energy-dispersed X-ray studies (SEM/EDAX) is mostly helpful to investigate the single-particle study. Estimation of light extremity accessible to the primeval beam is obtained by making a laser and the consequence can be adapted to a particle size distribution. A broad arrange of statistics can be acquired from color in terms of the creation and chemical arrangement of soil material ${ }^{16}$. The consequence of particle size on the reflectance spectra of soil specimen should also be regulated when the chemical properties of the soil specimen are to be found out. Particle size does not only contribute to distinction to the soil spectra among other factors are moisture content and soil order. ${ }^{17}$

\section{EXPERIMENTAL}

Experimental fieldwork was performed at Karisalpatti in Cheranmahadevi block, Tirunelveli district of Tamilnadu. The ground was to be ready by proper manure and tilth before one month of cultivation. Three plots were chosen. A control plot without applied organic manure was taken. In the next two plots $\mathrm{VC}, \mathrm{GM}+\mathrm{FYM}+\mathrm{VC}$ have applied at $17.5 \mathrm{tha}^{-1}$ concentration. The treated soil was made up of sandy loam soil structure and corn was planted. The Electrical Conductivity of the soil was calculated with (1:2.5 soil: water) potentiometry method ${ }^{18}$. Hydraulic conductivity was calculated using the constant pressure head method. A Constant Pressure Head is maintained on the top of a saturated soil column of known cross-sectional area and length ${ }^{19}$. The outflow on the bottom is collected over some time $(5 \mathrm{hr})$ and the outflow volume is determined. With known and determined quantities, the saturated hydraulic

conductivity was calculated as Hydraulic conductivity, $\mathrm{k}=\frac{q l}{A h t} \times 60 \mathrm{~cm} / \mathrm{hr}$. The flow of heat in the

sandy loam soil was due to the conduction of solar energy. Using Lee's Disc method the thermal conductivity of soil was determined. SEM and EDAX analysis provide the surface morphology and mineral composition of the soil sample. Using the dynamic light scattering technique the particle size of the soil sample was found out.

\section{RESULTS AND DISCUSSION}

\section{Electrical Conductivity (EC) and Hydraulic Conductivity (HC) Analysis}

Electrical conductivity values provide a significant role in whether the soil is capable to generate electricity ${ }^{20}$. Table 1 shows that before harvest the control plots had the maximum value of EC as $0.28 \mathrm{ds}$ $\mathrm{m}^{-1}$. After harvest, the control plot had the maximum value of EC as $0.18 \mathrm{ds} \mathrm{m}^{-1}$. Before harvest, the $\mathrm{HC}$ is found to be $2.1116 \mathrm{~cm} \mathrm{hr}^{-1}$ for $\mathrm{VC}$ at $17.5 \mathrm{t} \mathrm{ha}^{-1}$ greater than the control plot value at $1.8301 \mathrm{~cm} \mathrm{hr}^{-1}$. After harvesting the value of $\mathrm{HC}$ is found to be $2.0588 \mathrm{~cm} \mathrm{hr}^{-1}$ for $\mathrm{VC}+\mathrm{FYM}+\mathrm{GM}$ as $17.5 \mathrm{t} \mathrm{ha}^{-1}$ greater than the control plot as $1.7522 \mathrm{~cm} \mathrm{hr}^{-1}$. The soil particle with a high value of Electrical Conductivity leads to instability of soil structure ${ }^{21}$. Sandy soils have little water at high water potentials ${ }^{22}$.

Table-1: Conductivity Measurement

\begin{tabular}{|c|c|c|c|c|c|c|}
\hline \multirow{3}{*}{ S. No. } & \multirow{3}{*}{$\begin{array}{l}\text { Manure } \\
17.5 \mathrm{t} \mathrm{ha}^{-1}\end{array}$} & \multirow{2}{*}{\multicolumn{2}{|c|}{ Before harvest }} & \multirow{2}{*}{\multicolumn{2}{|c|}{ After harvest }} & \multirow{3}{*}{$\begin{array}{l}\text { Yield } \\
\mathrm{Kg} \mathrm{ha}^{-1}\end{array}$} \\
\hline & & & & & & \\
\hline & & $\mathrm{ECds} \mathrm{m}^{-1}$ & $\mathrm{HC} \mathrm{cm} \mathrm{hr}^{-1}$ & $\mathrm{EC} \mathrm{ds} \mathrm{m^{-1 }}$ & $\mathrm{HC} \mathrm{cm} \mathrm{hr}^{-1}$ & \\
\hline 1 & $\mathrm{VC}$ & 0.26 & 2.1116 & 0.09 & 1.9608 & 6686.25 \\
\hline 2 & $\mathrm{VC}+\mathrm{GM}+\mathrm{FYM}$ & 0.20 & 2.0086 & 0.08 & 2.0588 & 6493.50 \\
\hline 3 & $\begin{array}{c}\text { Control } \\
\text { (without manure) }\end{array}$ & 0.28 & 1.8301 & 0.18 & 1.7522 & 3494.50 \\
\hline
\end{tabular}




\section{Yield}

The yield was high in the triple manure concentration of FYM+GM+VC plot at $17.5 \mathrm{t} \mathrm{ha}^{-1}$ as $6493.5 \mathrm{Kg}$ $\mathrm{ha}^{-1}$. Similarly, the maximum yield was obtained by using vermicompost at $17.5 \mathrm{tha}^{-1}$ as $6686.25 \mathrm{Kg} \mathrm{ha}^{-1}$. For the control plot without organic manure, the value of yield was very low as $3494.5 \mathrm{Kg} \mathrm{ha}^{-1}$. The yield produced by the soil also increases due to the addition of organic manure. Similar results were obtained ${ }^{23}$.

\section{Thermal Conductivity Analysis}

The heat transfer of soils is characterized by soil process as water evaporation and diffusion. The highest thermal conductivity was observed in the substance for the enzyme acts on Quartz sand. The thermal properties of soil action invisibly exercise the energy in dividing the soil profile. The absorption of thermal energy in the soil is influenced by the soil heat attribute. The capacity to view the soil heat transfer is an important tool to maintain the soil temperature gradient which affects seed germination and crop growth. Using Lee's disc method the thermal conductivity of soil was determined and contrast to the control plot without organic manure. Lee's disc experiment consists of a steam chamber and metal disc with two thermometers as shown in Fig.-1. The soil sample was placed between the steam chamber and the metal disc. By producing the steam until the steady-state temperature was reached, the thermal conductivity of the sandy loam soil was determined. While applying the organic manure thermal conductivity decreases when contrast to the control plot as shown in Table-2. Low thermal conductivity of soil with organic manure reveals good crop productivity and enhanced water holding capacity.

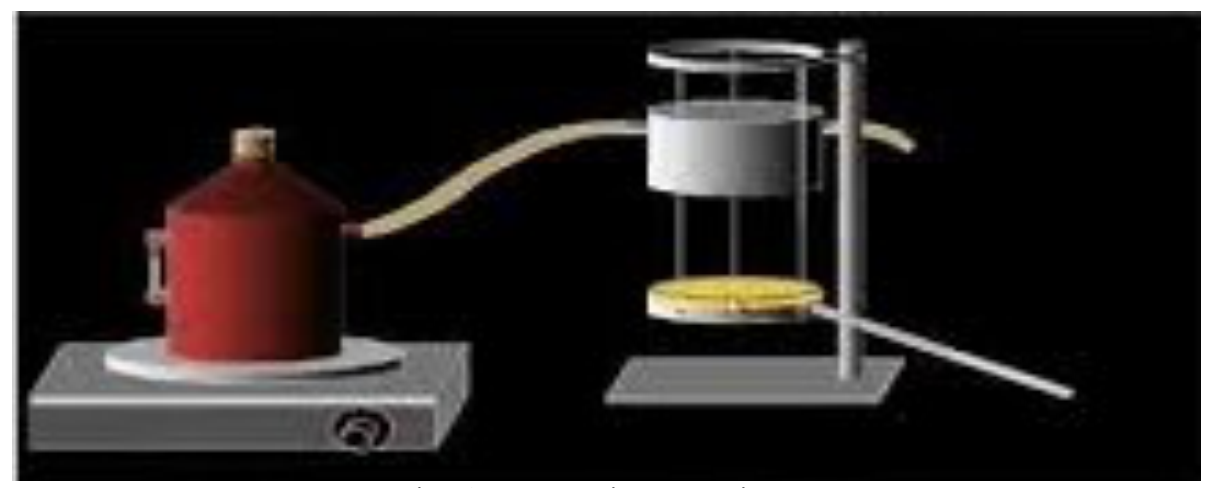

Fig.-1: Lee's Disc Experiment

Table-2: Soil Analysis Results for Thermal Conductivity (K)

\begin{tabular}{c|c|c}
\hline \multirow{2}{*}{$\begin{array}{c}\text { Manure } \\
17.5 \mathrm{t} \mathrm{ha}^{-1}\end{array}$} & \multicolumn{2}{|c}{ Thermal Conductivity $(\mathrm{K}) \mathrm{wm}^{-1} \mathrm{k}^{-1}$} \\
\cline { 2 - 3 } & Before Harvest & After Harvest \\
\hline $\mathrm{VC}$ & 0.3737 & 0.3488 \\
\hline $\mathrm{VC}+\mathrm{GM}+\mathrm{FYM}$ & 0.3762 & 0.3676 \\
\hline Control(without manure) & 0.4550 & 0.4255 \\
\hline
\end{tabular}

\section{Particle Size Analysis}

Soil incorporates a group of ensuing soil particles of different sizes. The entity of a particle size study is to analyze the particle into a different range of sizes and to evaluate the relative proportion by weight of each size range. The method employs filtering and the process of settling of a soil suspension to separate the particle. Patterning the size distribution of soil particles leads to a particle size distribution curve to know the pore distribution. The particle size studies of sandy loam soil were essential to predict the water holding capacity of the soil.

From the observed intensity distribution curve for the best yield soil samples, vermicompost and mixture of vermicompost, goat manure, and farm yard manure before and after harvest the particle size of the soil were more than the control plot which is due to the addition of organic manure shown in Table- 3 . After harvest for the organic amended plot such as vermicompost of single manure concentration and the mixing of vermicompost, goat manure, farmyard manure of triple manure concentration the particle size 
RASĀYAN J. Chem.

Vol. 14 | No. 1 |74-81| January - March | 2021

of the soil decreases which reveals the soil fertility, good water holding capacity and it is further responsible for crop productivity.
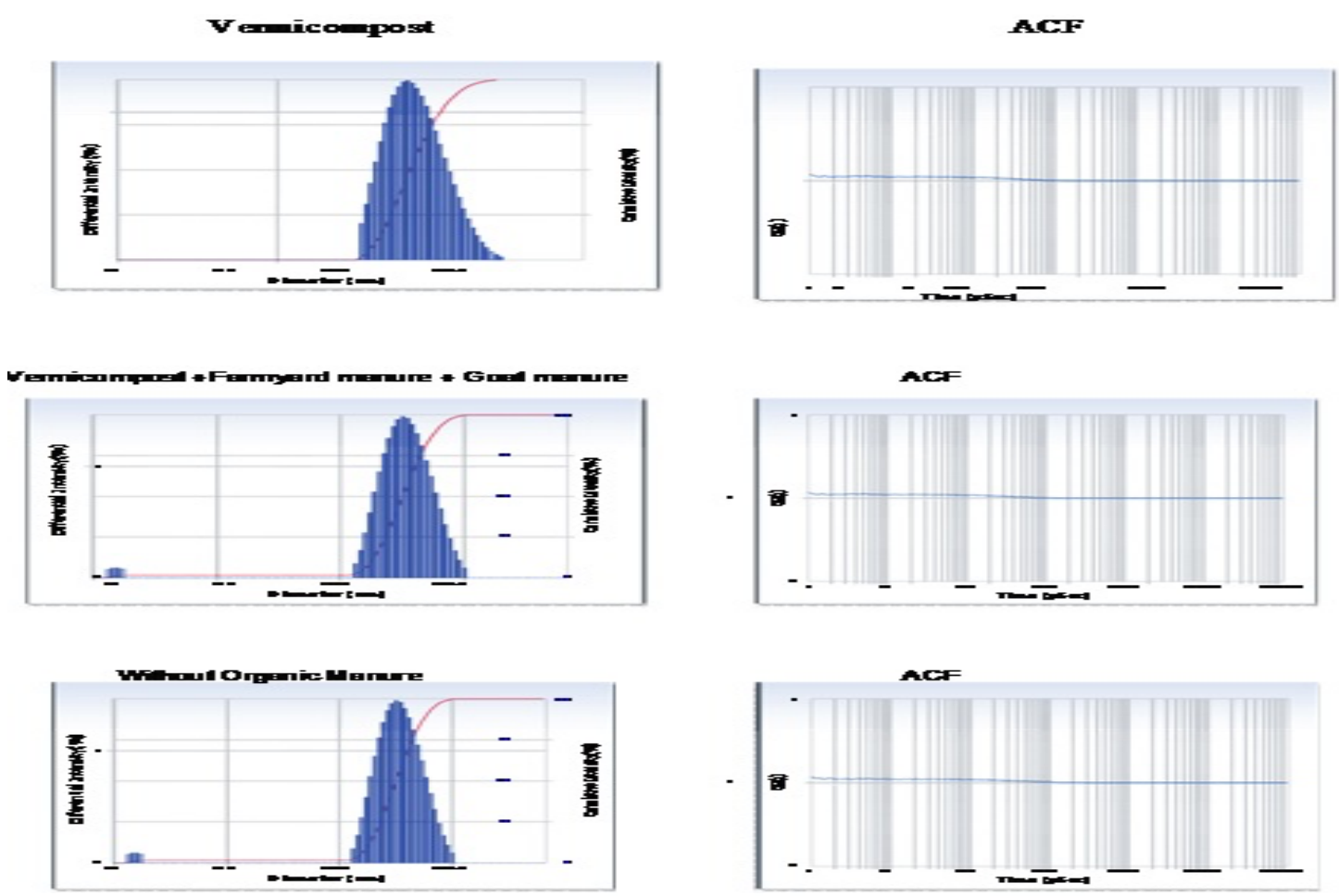

Fig.-2: Intensity Distribution Curve (Before Harvest)
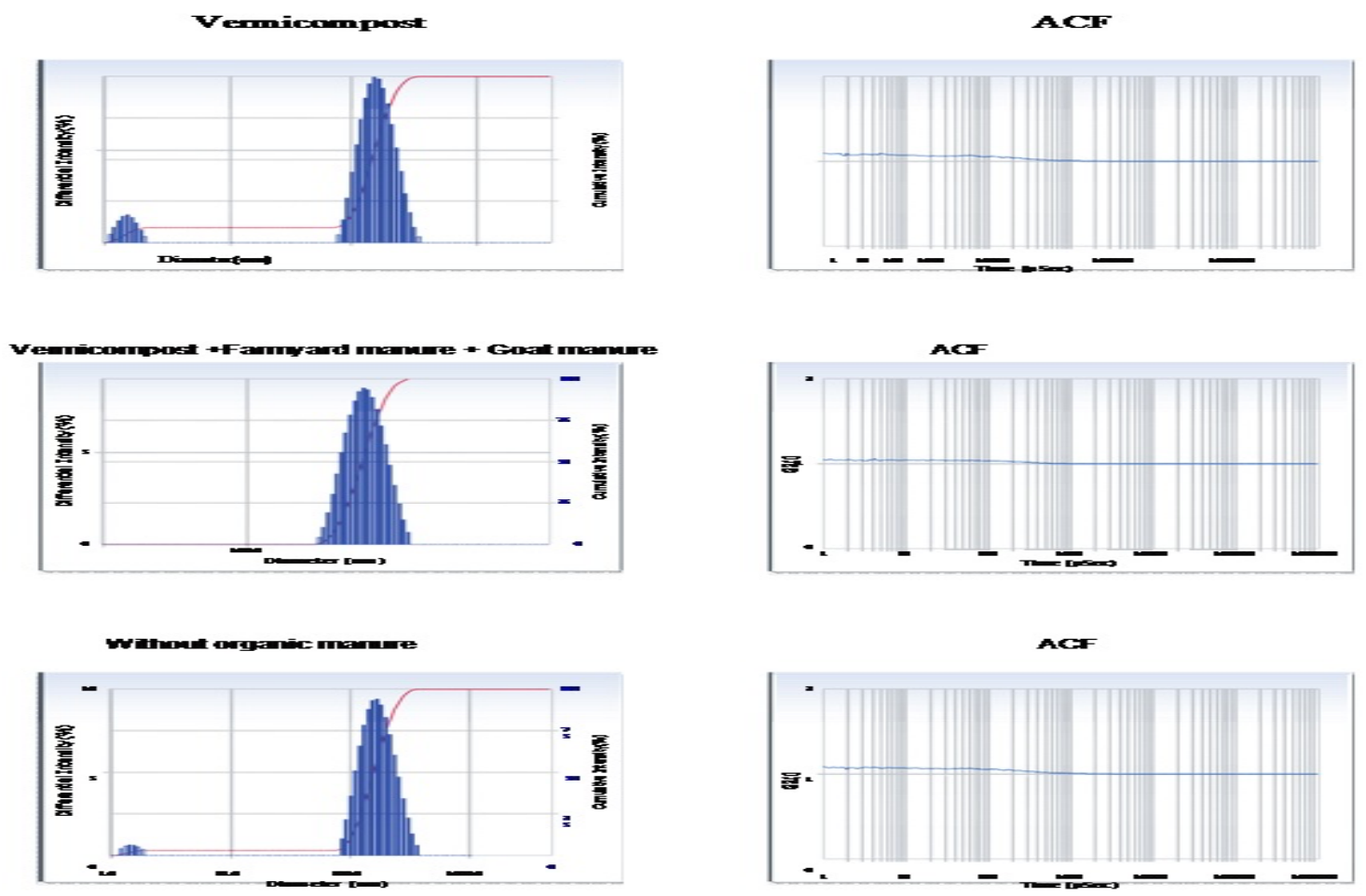

Fig.-3: Intensity Distribution Curve (After Harvest) 
But for the soil sample without organic manure after harvest the particle size increase shows that the soil toughness, less productivity and it was not responsible for further growth. The intensity distribution curve was shown in Fig.-2 and Fig.-3. The particle size intensity distribution curve is expressed in the nanometer range, before harvest, the vermicompost manure added sandy loam soil having the intensity value as $230.8 \mathrm{~nm}$ and after harvest it decreases to $155.5 \mathrm{~nm}$. Similarly, before harvest, the vermicompost, goat manure and farmyard manure added to sandy loam soil have an intensity value of $388.7 \mathrm{~nm}$ and after harvest, it decreases to $216.9 \mathrm{~nm}$. Before harvesting without organic manure, the particle size intensity value was low as $166.5 \mathrm{~nm}$ and after harvest, it increases to $180.4 \mathrm{~nm}$. Thus the particle size intensity distribution curve clearly explains the fertility of sandy loam soil increasing by using organic amendments when compared to the control plot without organic manure. In the time estate analysis, the ACF decays originate from zero to delay time and leads to speeder potent due to lower particles and also lead to reducing the correlation between signals of scattered intensity trace. The intensity autocorrelation function has the Fourier transformation of the power spectrum and thus dynamic light Scattering (DLS) measurements maintained in the spectral domain.

\section{SEM and EDAX Analysis}

SEM was used to investigate the external morphology characteristics for the sandy loam soil particles. The soil was colored, ranging from whitish to blackish due to the deposition of the small particles of black carbon. The presence of heavy metals was analyzed using an energy dispersive X-ray Spectrometer. The particle sizes of the soil sample were observed to be more agglomerated and heterogeneous. From the observed SEM crystallizations and morphologies, it is possible to identify the mineral phase in agglomeration. EDAX is an analytical technique that helps to analyze the elemental composition of the soil samples. From the EDAX spectrum, the elements such as $\mathrm{K}, \mathrm{O}, \mathrm{Mg}, \mathrm{Fe}, \mathrm{Al}, \mathrm{Ca}, \mathrm{Na}$, and $\mathrm{Si}$ are observed in the soil. The presence of Silicon mineral shows the semiconducting nature of the soil and it helps to generate electricity. Oxygen is used by plant roots and soil microbes during respiration. The observed minerals and elemental composition in the EDAX spectrum are varied using organic manure when compared to the control plot. After harvests the Ti mineral composition is present in vermicompost and control plot which shows that Ti minerals are resistant to weathering, they occur practically undecomposed in soil ${ }^{24}$. The presence of $\mathrm{Mg}$ is essential for photosynthesis and also helps to identify the dispersion of soil colloids which improves the surface sealing. Iron is required for the process of chlorophyll in plant cells. Potassium relatively immobile in soils but can leach in sandy soils. During low rainfall, year salt burn often show up in sandy soil. This salts burn is a combination of the accumulation of sodium within the soils by the use of well water and the low exchange capacity of the soils.
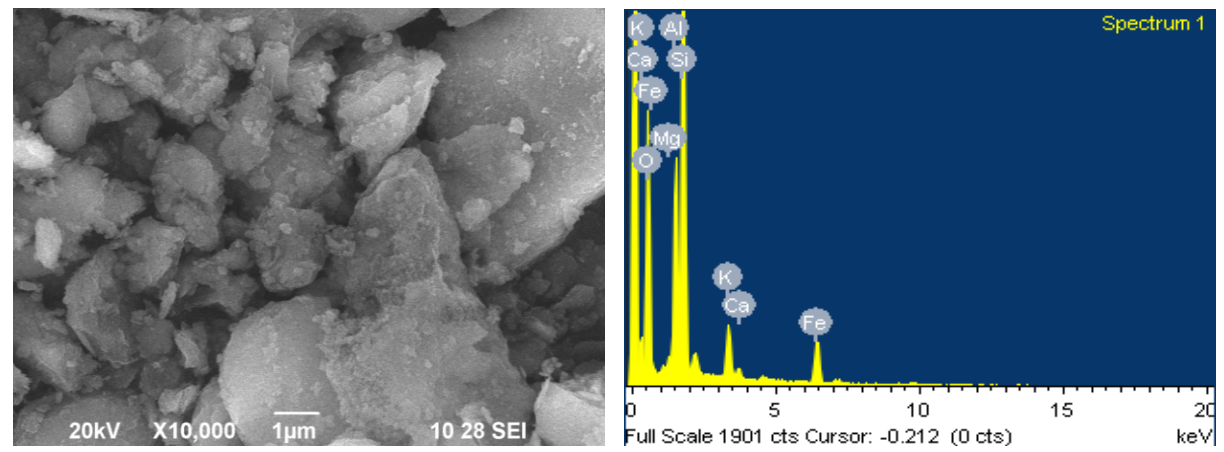

Fig.-4: SEM and EDAX Image for Vermicompost (Before Harvest)

The morphological appearance of vermicompost added sandy loam soil shown in Fig.-4 reveals that before harvest the SEM image appears to be small cylindrical shaped. The black color indicates the origin of silicon in the sandy loam soil. The elemental compositions such as $\mathrm{Ca}, \mathrm{Fe}, \mathrm{Mg}, \mathrm{O}, \mathrm{Si}, \mathrm{Al}$ are shown the $\mathrm{n}$ in the EDAX spectrum. The Silicon has an intensity range of $0.7868 \mathrm{~nm}$.

After harvest, the morphological appearance of vermicompost added sandy loam soil shown in Fig. -5 reveals that the SEM image appears to be intergranular spaces with sharp edges and it indicates the presence of heavy metal like Titanium in the sandy loam soil. The Titanium has an intensity range of $0.8188 \mathrm{~nm}$. 
RASĀYAN J.Chem.

Vol. 14 | No. 1 |74-81| January - March | 2021
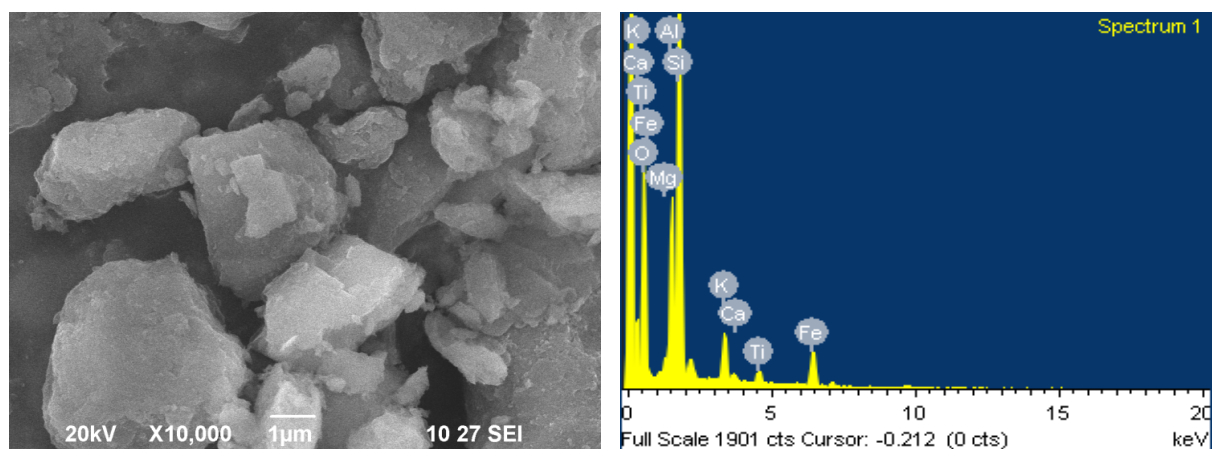

Fig.-5: SEM and EDAX Image for Vermicompost (After Harvest)
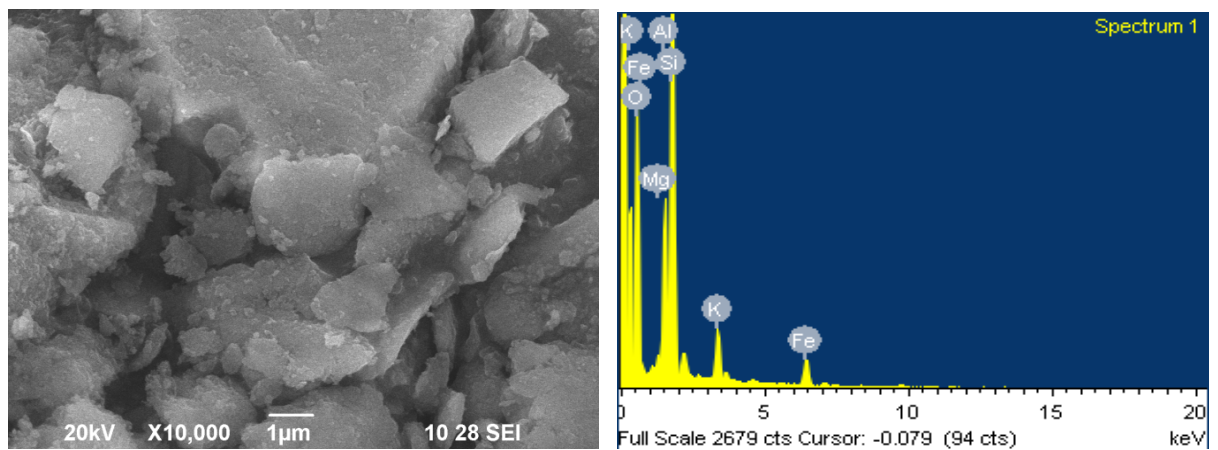

Fig.-6: SEM and EDAX Image for Vermicompost, Goat Manure, Farmyard Manure (Before Harvest)

The morphological appearance of vermicompost, farmyard manure and goat manure added to sandy loam soil shown in Fig.-6 contains the SEM image appearing to be irregular fragments in agglomeration. The EDAX spectrum reveals the presence of elemental composition such as $\mathrm{O}, \mathrm{Al}, \mathrm{Si}, \mathrm{K}, \mathrm{Fe}$ having intensity ranges at $1.0169 \mathrm{~nm}, 0.8318 \mathrm{~nm}, 0.8134 \mathrm{~nm}, 0.9899 \mathrm{~nm}$ and $0.8259 \mathrm{~nm}$.
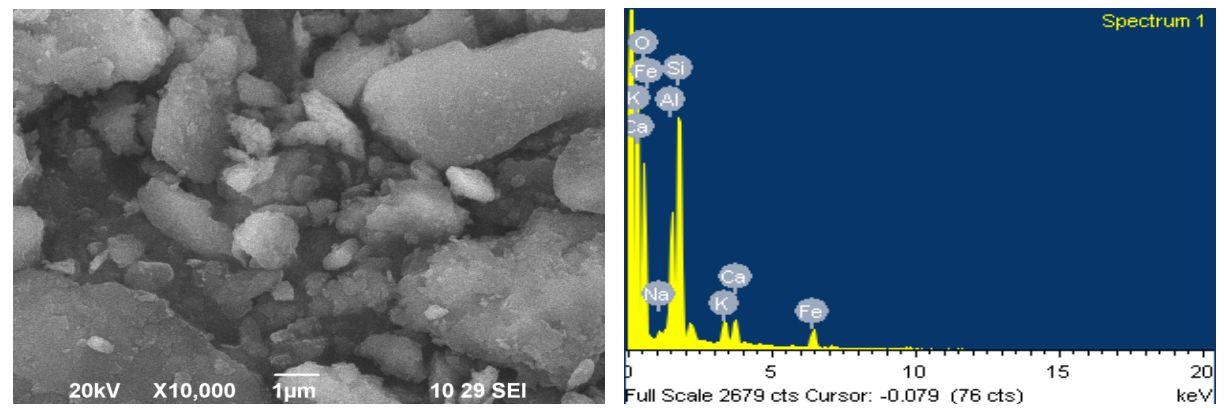

Fig.-7: SEM and EDAX Image for Vermicompost, Goat Manure, Farmyard Manure (After Harvest)

The SEM image appears to be a small cylindrical shape with a smoothly polished surface. The EDAX spectrum indicates the mineral composition of an element such as $\mathrm{O}, \mathrm{Al}, \mathrm{Si}, \mathrm{K}, \mathrm{Fe}$ having the intensity ranges at $0.9576 \mathrm{~nm}, 0.8180 \mathrm{~nm}, 0.7950 \mathrm{~nm}, 1.0040 \mathrm{~nm}, 0.8264 \mathrm{~nm}$ and sodium as $0.7397 \mathrm{~nm}$. Oxygen content was more in an organic amended plot.
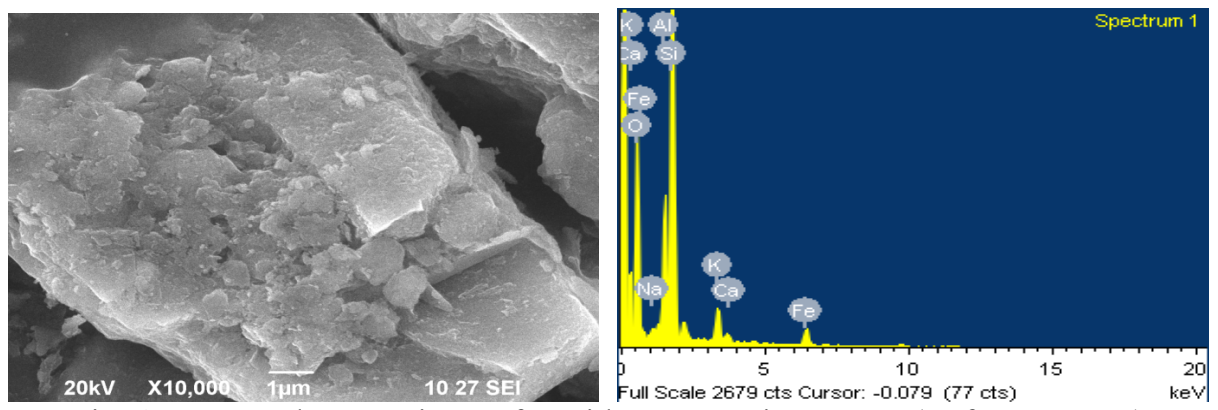

Fig.-8: SEM and EDAX image for without Organic Manure (Before Harvest) 
The SEM image size appears to be large for the soil sample without organic manure. Here the EDAX elements present are Oxygen at $0.9583 \mathrm{~nm}$, Aluminium at $0.8553 \mathrm{~nm}$, Silicon at $0.8347 \mathrm{~nm}$, Potassium at $0.9820 \mathrm{~nm}$ and Iron at $0.8251 \mathrm{~nm}$.

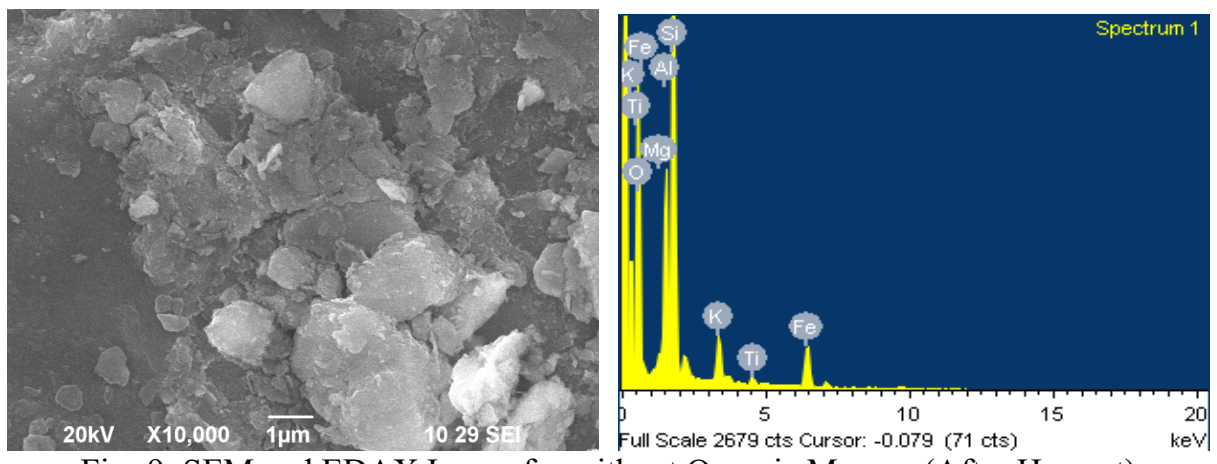

Fig.-9: SEM and EDAX Image for without Organic Manure (After Harvest)

\section{CONCLUSION}

Before and after harvest the conductivity properties such as Electrical Conductivity (EC), Thermal Conductivity $(\mathrm{K})$ and Hydraulic Conductivity $(\mathrm{HC})$ were determined. The observed conductivities varied than the control plot. Before harvest the control plots had the maximum value of EC as $0.28 \mathrm{ds} \mathrm{m}^{-1}$. After harvest the control plot had the maximum value of $\mathrm{EC}$ as $0.18 \mathrm{ds} \mathrm{m}^{-1}$. Before harvest the $\mathrm{HC}$ is found to be $2.1116 \mathrm{~cm} \mathrm{hr}^{-1}$ for $\mathrm{VC}$ at $17.5 \mathrm{t} \mathrm{ha}^{-1}$ greater than the control plot value as $1.8301 \mathrm{~cm} \mathrm{hr}^{-1}$. After harvest, the value of $\mathrm{HC}$ is found to be $2.0588 \mathrm{~cm} \mathrm{hr}^{-1}$ for $\mathrm{VC}+\mathrm{FYM}+\mathrm{GM}$ at $17.5 \mathrm{t} \mathrm{ha}^{-1}$ greater than the control plot as $1.7522 \mathrm{~cm} \mathrm{hr}^{-1}$. In all the organically amended plots the electrical conductivity and thermal Conductivity values decrease than the control plot. The Hydraulic Conductivity values increased than the control plot. It positively originates the yield. Low thermal conductivity of soil with organic manure reveals as good crop productivity and has good water holding capacity. From the observed SEM crystallizations and morphologies it is possible to identify the mineral phase in agglomeration. The observed minerals and elemental composition in the EDAX spectrum are varied with organic manure. For organic amendment plot such as vermicompost (VC) at $17.5 \mathrm{t} \mathrm{ha}^{-1}$ and also Farm Yard Manure (FYM), Vermicompost (VC) and Goat Manure (GM) at $17.5 \mathrm{t} \mathrm{ha}^{-1}$ after harvest the particle size of the soil decreases which reveals the soil fertility and enhanced the water holding capacity.

\section{ACKNOWLEDGMENT}

I, P.Jeyaseeli (Reg.No: 18121072132021) thankful to authorities of the Department of Physics, Sarah Tucker College (Autonomous), Tirunelveli, PG and Research Department of Physics, M.D.T. Hindu College, Tirunelveli and we would also like to thank Manonmaniam Sundaranar University, Abishegapatti, Tirunelveli, Tamilnadu, India for providing necessary research facilities.

$\begin{array}{ll}\text { Abbreviations: } & \\ \text { FYM } & \text { Farm Yard Manure } \\ \text { GM } & \text { Goat Manure } \\ \text { VC } & \text { Vermicompost } \\ \text { C } & 17.5 \mathrm{t} \mathrm{ha}^{-1} \\ \text { EC } & \text { Electrical Conductivity } \\ \text { HC } & \text { Hydraulic Conductivity }\end{array}$

\section{REFERENCES}

1. V. Gashi, B. Kelmendi, N. Shala, I. Cacaj, O. Gashi, and V. Havolli, Rasayan Journal of Chemistry, 12(3), 1540 (2019), DOI:10.31788/RJC.2019.1235301

2. $\quad$ E. C. Brevik, and T. J. Saucer, Soil, 1(1), 35(2015), DOI:10.5194/soil-1-35-2015

3. M. A. Akanji, S. O. Oshunsanya, and A. Alomran, International Soil and Water Conservation Research, 6(3), 230(2018), DOI: 10.1016/j.iswcr.2018.03.006

4. Suherman, A. K. Rosyidah, A. Suratman, N. H. Aprilita, Mudasir, and K. Morita, Rasayan Journal of Chemistry, 12(3), 1279(2019), DOI:10.31788/RJC.2019.1235203 
RASĀYAN J. Chem.

Vol. 14 | No. 1 |74-81| January - March | 2021

5. R. Kaur, M. Bansal, S. Sharma, and S. Tallapragada, Rasayan Journal of Chemistry, 12(2), 421(2019), DOI:10.31788/RJC.2019.1225160

6. M. Kavisri, P. Senthilkumar, M. S. Gurukumar, and K. J. Pushparaj, Rasayan Journal of Chemistry, 11(1), 111(2018), DOI:10.7324/RJC.2018.1111805

7. A. Manimaran, S. Santhosh, and P. T. Ravichandran, Rasayan Journal of Chemistry, 11(1), 401 (2018), DOI:10.7324/RJC.2018.1112044

8. $\quad$ R. Gothwal, and G.K.Gupta, World Scientific News, 115, 117(2018).

9. A. H. J. Haghigh, J. Shamshuddin, J. Hamdan, and N. Zainuddin, Open Geosciences, 8(1), 503(2016), DOI: 10.1515/geo-2016-0034

10. S. A. Bhat, J. Singh, and A. P. Vig, Springerplus, 4, 11(2015), DOI: 10.1186/s40064-014-0780-y

11. A. Bruand, C. Hartmann, S. R. Anupap, P. Sidhusen, and M. Hardy, Soil Science Society of America Journal, 68(1), 185(2004), DOI:10.2136/sssaj2004.1850

12. S. I. Hwang, and S. P. Hong, Geoderma, 133(3-4), 421(2006), DOI:10.1016/j.geoderma.2005.08.006

13. S. I. Hwang, K. P. Lee, D. S. Lee, and S. E. Power, Soil Science Society of America Journal, 66(4), 1143(2002), DOI:10.2136/sssaj2002.1143

14. J. Torrent, and V. Barron, EJ (2 editions) Soil Color, SSSA Spectra Publications, 31, 21(1993), DOI: $10.2136 /$ sssaspecpub31.c2

15. A. U. Bappa, and A. Haruna, Journal of Applied Sciences \& Environmental Management, 19(3), 403(2015), DOI: 10.4314/jasem.vi3.9

16. M. F. Baumgardner, L. F. Silva, L. L. Bieh, and E. R. Stoner, Advances in Agronomy, 38, 1(1985), DOI:10.1016/S0065-2113(08)60672-0

17. L. J. Janik, R. H. Merry, S. T. Forester, D. M. Lanyon, and A. Rawson, Soil Science Society of America Journal, 71(2), 507(2007), DOI:10.2136/sssaj2005.0391

18. M. L. Jackson, Soil Chemical Analysis, Prentice Hall, New Delhi, $1^{\text {st }}$ edition, p. 89(1973).

19. O. W. Israelson, V. E. Hansen, Irrigation Principles and Practices $3^{\text {rd }}$ edtion, John Wiley and Sons Inc., New York, 1(1962).

20. R. Prathiba, and R. Karthikeyan, Journal of chemical and pharmaceutical Science, 7, 338(2015).

21. J. R. S. Abad, H. Khosravi, and E. H. Alamdarlou, Bulletin of Environment, Pharmacology and Life Sciences, 3(3), 296(2014).

22. P. Sangwan, C. P. Kaushik, and V. K. Garg, Waste Management \& Research: The journal for a Sustainable Circular Economy, 28(1), 71(2010), DOI:10.1177/0734242X09336315

23. F. Jeyamangalam, and P. Jeyalakshmi, Journal of Modern Science, 8(1), 33(2018).

24. S. Cornu, Y. Lucas, E. Lebon, J. P. Ambrosi, F. Luzizao, J. Rouiller, M. Bonnay, and C. Neal, Geoderma, 91(3-4), 281(1999), DOI:10.1016/S0016-7061(99)00007-5

[RJC-6119/2020] 